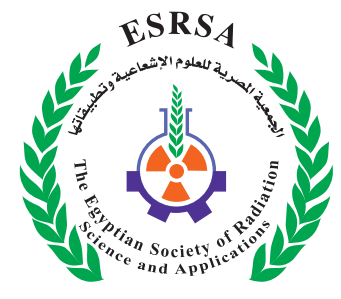

J. Nucl. Tech. Appl. Sci., Vol. 6, No. 2, PP. $127: 125$ (2018)

\title{
Evaluation of a Primary Treatment Unit for the Cooling Water of a Nuclear Power Plant
}

Tawfik, M.S. and Tawfik, F.S.

Received: 05/05/2018

Accepted: 25/06/2018

E.mail:m_tawfik7@hotmail.com

\section{KEYWORDS}

Cooling Water, Biofouling, Debris Filter, Primary Treatment.

\section{ABSTRACT}

It is essential to have an effective treatment program and control methodology for a nuclear power plant cooling water system. As the accumulation and growth of cooling water deposits reduce the overall heat transfer coefficient and have an adverse effect on the operation of equipments, plant availability, production, and maintenance cost. The study aims at evaluationof using a primary treatment unit debris filter as a controlling of fouling formation, in a nuclear power plant located in coastal area. Selecting Sedi kerir, and Sidi Abdelrahman cooling water channel for the proposed nuclear power plant. Samples of the two selected sites had been taken and some physicochemical and biological parameters were analyzed such as $(\mathrm{pH}$, total alkalinity, total dissolved solids, suspended solids, temperature and total count of microalgae). A mathematical model has been used also in order to help in evaluation of the suggested pretreatment unit. The results has showed that sea water temperature used at the two selected sites (Sidi kerir, and Sidi Abdelrahman below $125^{\circ} \mathrm{F}$ that mean low fouling factor, also the measured physicochemical and biological parameter concentrations at the proposed two selected sites increase the probability of fouling formation at these sites. As a using of suggested debris filter pretreatment unit for cooling water at the two selected sites, will help in decreasing the probability of fouling formation at these site.

1. Nuclear Radiological Regulatory Authority. 


\section{INTRODUCTION}

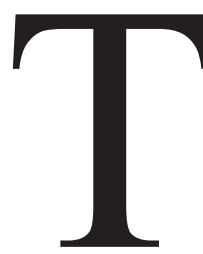

he three basic types of cooling water systems are once-through, closed recirculation (non-evaporative), and open recirculation (evaporative). The basic concept operation of once through cooling system; where the water passes though heat exchanger equipment only once. The runoff water temperature increases slightly due to using large volumes of cooling water. The mineral content of the cooling water remains practically unchanged as it passes through the system (Abdulmajed, 2012).

The using of pre-screening cooling water intakes, additional filtration may be required at locations where the cooling water is loaded with heavy debris and marine life .The accumulation and growth of cooling water deposits reduce the overall heat transfer coefficient and will have an adverse effect on the operation of process equipment, plant availability, production, and maintenance cost. Traditionally, power plant maintenance teams isolate and open each heat exchanger or condenser unit periodically in order to clean the tubes manually using high-pressure water jets or mechanical scrapers (Stanford, 2003). Debris filters provided a vital line of defense, efficiently intercepting and removing excessive materials related to problems downstream, preventing them from entering the heat exchangers or condenser. Intake screens are often ineffective in protective heat exchanger tubes from debris. Many plants designed with through -flow traveling screens located upstream of the condenser still experience heavy debris carryover or are victims of macro fouling via mollusk or crustacean growth with intake tunnel, which causes many clogged condenser tubes. A debris filter or automatic pipe strainers provide the best filtration, ranging from 50 microns to $10 \mathrm{~mm}$ (Abdulmajed, 2012). These strainers can be sized to remove the carryover and fine debris that pass through intake screens to prevent buildup inside the condenser or exchanger tubes. Debris larger than the mesh size is trapped over the screen area. The flow rate affect the formation of fouling as at low flow rates, $1 \mathrm{ft} / \mathrm{s}(0.3 \mathrm{~m} / \mathrm{s})$ or less, fouling occurs due to natural settling of suspended material. At higher flow rates, $3 \mathrm{ft} / \mathrm{s}(0.9 \mathrm{~m} / \mathrm{s})$ or more, fouling can still occur, but usually at a lower rate so that accumulation is less severe. Fouling formation depend on chemical characteristics of water. Most waters contain suspended materials that can cause a significant fouling problem under certain conditions. The amount of suspended material directly affects the amount of fouling that can occur on system surfaces. Lower dissolved solids, reduces fouling potential and higher amounts increase the fouling potential. Fouling can be controlled mechanically or by the use of chemical treatments. Continuous control of the mechanical, operational, and chemical (MOC) aspects of the system and treatment program is the only way to reduce fouling (Stanford, 2003). It is essential to have an effective treatment program and control methodology. The most important forms of fouling occurring in seawater systems; 1) Crystallization-fouling. This includes the deposition of calcium carbonate, calcium sulfate and other salts that have a solubility that diminishes with increasing temperature, leading to crystallization of deposits of the salts on the heat exchanger tubes, 2) Corrosion fouling, some metals are oxidized to produce insulating layers of oxides on the tubes,3) Biological fouling. It is a biological growths form on heat exchanger tubes in seawater. The species attached range from micro-organisms (bacteria, algae) to macro-organisms (mussels, barnacles, etc.). Particulate fouling seawater may contain many types of silt, mud, sand or other finely divided particles that may settle on the heat exchanger surfaces and act as an insulating layer (Pugh, 2003). 
Table (1) : Normal fouling factors (Pugh, 2003).

\begin{tabular}{|c|c|c|}
\hline \multirow{2}{*}{ Types of fluids } & \multicolumn{2}{|c|}{ Fouling factor } \\
\cline { 2 - 3 } & $\mathbf{h . f t}^{2} \mathbf{. F} / \mathbf{B T U}$ & $\mathbf{~ m}^{2} \cdot \mathbf{C}^{2} / \mathbf{W}$ \\
\hline Sea water below $125^{\circ} \mathrm{F}$ & 0.0005 & 0.00002 \\
Sea water above $125^{\circ} \mathrm{F}$ & 0.001 & 0.002 \\
Treated boiler feed water above $125^{\circ} \mathrm{F}$ & 0.001 & 0.0002 \\
Fuel oil & 0.005 & 0.0009 \\
Quenching oil & 0.004 & 0.0007 \\
Alcohol vapors & 0.005 & 0.00009 \\
Industrial air & 0.002 & 0.004 \\
Refrigerating liquid & 0.001 & 0.0002 \\
\hline
\end{tabular}

\section{MATERIALS AND METHODS}

In order to evaluate two proposed sites which are Sedi kerrir and Sedi Abdel Rahaman have been selected as pretreatment cooling water systems with debris filter as seen in Fig. (1) Suggesting a pretreatment cooling water system with debris filter would be with fineness degrees of approx $5-9 \mathrm{~mm}$, which eliminates macro fouling from large volume flow, even beyond $100,000 \mathrm{~m}^{3} / \mathrm{h}$. Using turbine condensers, and heat exchangers downstream. Determination of fouling factor effects on the suggested cooling water system, analyzing some chemical parameters which help in evaluation the efficiency of heat transfer coefficient and the mitigation of fouling formation, such as; turbidity, total dissolved solids, suspended solids, temperature and total count of microalgae ,using (standard method for examination of water and wastewater, (APHA et al., 1995).

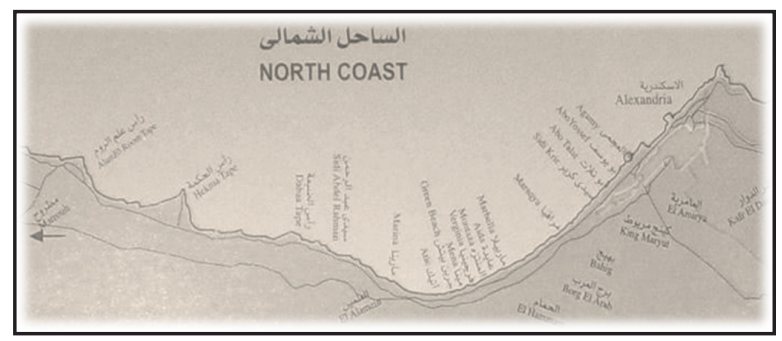

Fig. (1): Map showing sampling sites of coastal region (www.english.ahram.org.eg).

\section{RESULT AND DISCUSSION}

Table (2) shows that the highest mean average value of temperature during the 6 months was found at Sidi Abdelrahman site $\left(27^{\circ} \mathrm{C}\right)$ while the lowest mean average value are found sidi kerir $\left(25^{\circ} \mathrm{C}\right)$. The temperature is important factor in controlling macrobiofouling (PInan, 1986) and (Sun-Kyung Sung, 2008). Table (1) shows that the highest mean average value of suspended solid was found at Sidi Abdelrahmansite $13456 \mathrm{mg} / \mathrm{L}$, while the lowest one was found at Sidikerir site $11000 \mathrm{mg} / \mathrm{L}$. These values are complying with the limits of marine suspended solids at these regions, but also increase the possibility of chemical fouling when using one of the two selected sites as source of cooling water intake in a nuclear or thermal power plant. Table (2) shows that the highest mean average value of total count of microcroalge was found at Sidikirer 34567 cell/L while the lowest value was found at Sidi Abdelrahman 23456 cell/L. These values were complying with value measured in that marine area, on the other hand these values also increase the possibility of bio-fouling when selecting any of these sites as intake cooling water source for a nuclear or thermal power plant. As the result the using of equation (1). 
Table (2) : Average means of physicochemical and biological parameters of the selected sits during the period 12/1/2017 to 12/6/2017.

\begin{tabular}{|c|c|c|c|c|c|c|c|}
\hline Site & $\begin{array}{c}\text { Temp } \\
\mathbf{I n}^{\boldsymbol{}} \mathbf{C}\end{array}$ & $\mathbf{p H}$ & $\begin{array}{c}\text { Total } \\
\text { dissolved } \\
\text { solids } \\
\mathbf{m g} / \mathbf{L}\end{array}$ & $\begin{array}{c}\text { Dissolved } \\
\mathbf{0 x y g e n} \\
\mathbf{m g} / \mathbf{L}\end{array}$ & $\begin{array}{c}\text { Total } \\
\text { Alkalinity } \\
\text { (mg/L as } \\
\mathbf{C a C O} \text { ) }\end{array}$ & $\begin{array}{c}\text { Suspended } \\
\text { solids } \\
\text { (mg/L) }\end{array}$ & $\begin{array}{c}\text { Total count of } \\
\text { microalgae } \\
\text { (cell/L) }\end{array}$ \\
\hline Sidi kerir & 25 & 8.3 & 26788 & 10.4 & 220 & 11000 & 34567 \\
\hline $\begin{array}{c}\text { Sidi Abdel } \\
\text { Rahman }\end{array}$ & 27 & 8.5 & 25045 & 8.8 & 300 & 13456 & 23456 \\
\hline
\end{tabular}

The fouling factor can be determined as

$\mathrm{Ud}=1 /(\mathrm{Rd}+1 / \mathrm{U})^{(3)}$

Where:

$\mathrm{Rd}=$ fouling factor - or unit thermal resistance of the deposit $\left(\mathrm{m}^{2} \mathrm{~K} / \mathrm{W}\right)$

$\mathrm{Ud}=$ thermal conductance of heat exchanger after fouling $\left(\mathrm{W} / \mathrm{m}^{2} \mathrm{~K}\right)$

$\mathrm{U}=$ thermal conductance of clean heat exchanger $\left(\mathrm{W} / \mathrm{m}^{2} \mathrm{~K}\right)$.

Seawater below $325 \mathrm{~K}$ : $\mathrm{Rd}=0.00009\left(\mathrm{~m}^{2} \mathrm{~K} / \mathrm{W}\right)$

Seawater above $325 \mathrm{~K}: \mathrm{Rd}=0.0002\left(\mathrm{~m}^{2} \mathrm{~K} / \mathrm{W}\right)$

The fouling factor represents the theoretical resistance to heat flow due to a buildup of a layer of dirt or other fouling substance on the tube surfaces of the heat exchanger but they are often overstated by the end user in an attempt to minimize the frequency of cleaning. In reality they can, if badly chosen, lead to increased cleaning frequency. Fouling factors must be obtained experimentally by determining the values of $U$ for both clean and dirty conditions in heat exchanger. In our case, suggesting using thermal conductance of clean heat exchanger $=1961 \mathrm{~W} /$ $\mathrm{m}^{2} \mathrm{~K}$ (Pugh, 2003)

So, $\mathrm{R}_{\mathrm{f}}=1 / \mathrm{U}$ dirt $-1 / \mathrm{U}$-clean

When the measured temperature $=27^{\circ} \mathrm{C}$, it gives $80^{\circ} \mathrm{F}$ (below $125^{\circ} \mathrm{F}$ ) and also gives $300 \mathrm{Kelvin}$, that is mean ,Seawater below $325 \mathrm{~K}$ : Rd $0.00009\left(\mathrm{~m}^{2} \mathrm{~K} / \mathrm{W}\right)$.
The value of U-dirt will be 1886.9 by using equation (2) As the result, the reduction percent in the convection of heat transfer coefficient will be $3.7 \%$ in that suggested sea water temperature area, on the other hand, the presence of the microalgae and suspended solids at the selected cooling sites, help in enforcing the formation of fouling inside the suggested NPP condenser tubes, as a result the suggesting of a pretreatment cooling water system at the selected sites (Sidi kerir, and Sidi Abdel Rahman) would help in mitigation of the fouling impacts at the suggested cooling water system of a nuclear power plant and keeping a suitable convection of heat transfer coefficient inside their pipes (PInan,1986).

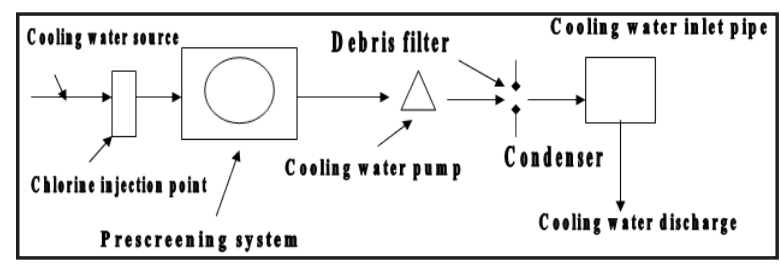

Fig. (2): Suggesting a Diagram of a pretreatment unit for Cooling water channel selected site.

The suggested fouling diagram as showed in figure (2) consist of both chemical and physical treatment units in which chemical unit concerned in chlorination injection system with shock dose $(10 \mathrm{mg} / \mathrm{L})$ at inlet cooling intake structure as showed in figure (2) where physical treatment are concerned in a prescreen followed by debris filter as described in material and method. This suggested diagram helps in the mitigation of biofouling formation probability in the two selected sites when using as cooling water in- 
take source for a thermal or nuclear power plant, and it had been used in Abou-Qir thermal power plant cooling water system (Tawfik, 2001).

\section{CONCLUSION}

- Sea water temperature used at the two selected sites (Sidi kerir, and Sidi Abdel Rahman) are below $125^{\circ} \mathrm{F}$ that mean with low fouling factor $(0.00002$ $\left.\mathrm{m}^{2} .{ }^{0} \mathrm{C} / \mathrm{w}\right)$. on the other hand, the measured physicochemical and biological parameter concentrations at the two selected sites increase the probability of fouling at these sites. So that suggesting a pretreatment unit for cooling water at the two selected sites will decrease the probability of fouling formation at the selected site.

\section{REFERENCES}

- Saeed, A.M.A. (2012): Performance Analysis of the Automated Control System for Condenser Water treatment Unit. The using of prescreening cooling water intakes, additional filtration. Engineering, (4): 55.

- $\quad$ APHA, AWWA, WPCF (1995): Standard Methods for Examination of Water and Wastewater, Washington, D.C, $19^{\text {th }}$ edition.
- Stanford, H.W. (2003): HVAC Water Chillers and Cooling Towers Fundamentals, Application and Operation, Mar-cel Dekker, Inc., New York, (https://www.crcpress.com/HVAC-Water-Chillers-and-Cooling-TowersFundamentals-Application-and-Operation)

- North coast map: www.english.ahram.org.eg

- PInan, J.P.H. (1986): Heat transfer text book. Six edition, Mc Graw Hill publisher, 526-230.

- Pugh, S.J.; Hewitt, G.F. and Muller-Steinhagen, H. (2003): Fouling During theof seawater Development of a' User Guide' Engineering Conferences International of Heat Exchanger Fouling and Cleaning; Fundamentals and Applications.UK. (https://pdfs.semanticscholar.org)

- $\quad$ Sung, S.K.; Suh, S.H and Dong, W. (2008): Characteristics of cooling water fouling in a heat exchanger system, J. Mech. Sci. Technol., (22): 1568.

- Tawfik, M.S. (2001): Comparative study between wastewater resulted from Abo-Qir Power plant and wastewater resulted from El-Seiouf power plant due to their fuels. Master degree. Alexanderia University. 


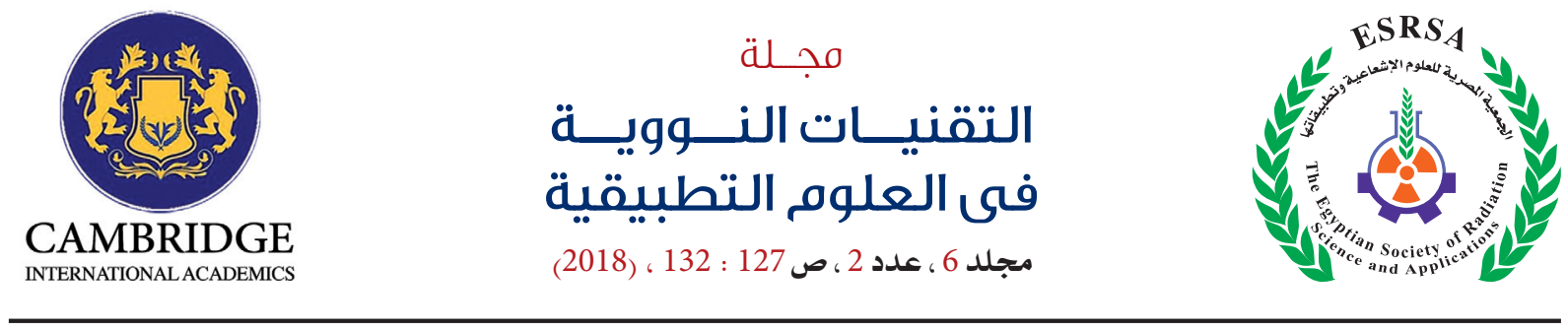

\title{
تقييم استخدام وحدة معالجه ابتدائيه لمياه التبريد الخاصه بمحطه توليد للقوى النوويت
}

\author{
محمد صفوت وفاتن صلاح توفيق
}

نظام مياة التبريد للهحطات النوويت الداخل والخارج للبحر من اهم الأنظمت المؤثرة علي

البيئت وكذلك علي كفاءة تشغيل المحطتة ولذلك من الضروري أن يكون هنالك برنامج فعال

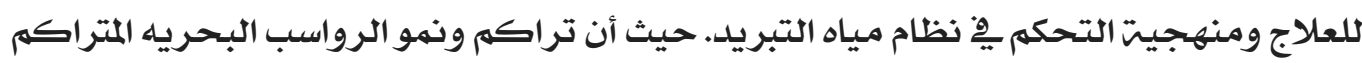
داخل انابيب التربيد يخفضان معامل التحويل الحراري الإجمالي وسيكون لهما تأثير سلبي على تشغيل معدات المعالجت وكذلك زياده تكاليف التثغيل والصيانت ولذلك تهتم هذة الدراست باقتر اح نظام معالجه ابتدائيه مسبقه للتحكم مِ تقليل تكون الرسوبيات، فِ محطت للطاقت نوويت المقترح دراستها يِ المنطقت الساحليت المختاره. وقد تم اختيار منطقتي سيدي كيرير وسيدي عبد الرحمن كقناة ومصدر لمياه تبريد لمحطت الطاقت النوويت المقترح اقامتها يِّ الضبعت. وقدتم اخذي العينات من المنطقتين الساحلتين موضع الدراسـه وقد تم ايضـا تحليل بعض العوامل الفيزيائيت ,الكيميائيت والبيولوجيه مثل (الأس الهيدروجيني، القلويه، المواد الصلبت الذائبت الكليتة المواد الصلبت العالق، درجت الحرارة والعدد الكلي للطحالب الدقيقت) للمساعدة فِّ تقييم وحدة المعالجت المقترحتّوقد تم استخدام النموزج الرياضى لحساب معامل الروسوبيات فى مياه موقع الدراسه وقد أظهرت النتائج أن درجت حرارة مياه البحر المستخدمت يِّ الموقعين المختارين (سيدي كرير، وسيدي عبد الرحمن أقل من 1250 فهرنهايت والتي تعني انخفاض معامل الروسوبيات

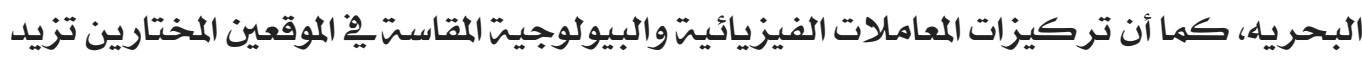

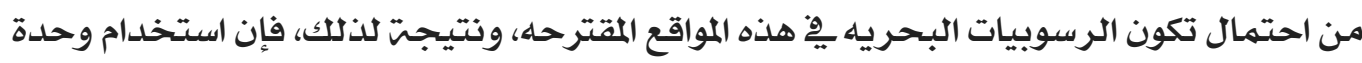

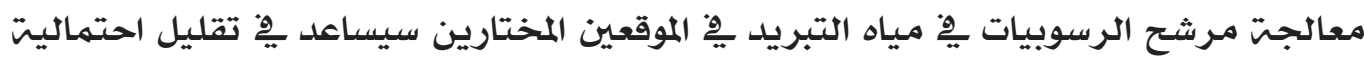
تكون الرسوبيات البحريه بهما. 